\title{
Evaluation of effects caused by differentially spliced Ets-1 transcripts in fibroblasts
}

\author{
JENS CLAUS HAHNE ${ }^{1}$, TANJA FUCHS ${ }^{2}$, ALEXANDRA FLORIN ${ }^{2}$, DYLAN EDWARDS $^{3}$, \\ ALBIN POURTIER $^{4,5,6}$, FABRICE SONCIN ${ }^{4,5,6}$ and NICOLAS WERNERT ${ }^{2}$ \\ ${ }^{1}$ Department of Obstetrics and Gynecology, University of Würzburg, D-97080 Würzburg; \\ ${ }^{2}$ Institute of Pathology, University of Bonn, D-53011 Bonn, Germany; ${ }^{3}$ School of Biological Sciences, \\ UEA-Norwich, Norwich, Norfolk NR4 7TJ, UK; ${ }^{4}$ Universite de Lille Nord de France, F-59000 Lille; \\ ${ }^{5}$ CNRS, UMR8161, F-59021 Lille Cedex; ${ }^{6}$ USTL, UCCS, F-59650 Villeneuve d'Ascq, France
}

Received April 28, 2011; Accepted June 27, 2011

DOI: $10.3892 /$ ijo.2011.1152

\begin{abstract}
The transcription factor Ets-1 is known to be involved in a broad variety of cellular functions such as cell proliferation, migration, invasion, apoptosis and angiogenesis. In nearly all these reports, the full-length Ets-1 (p51) is commonly considered to be the active form and the role of the Ets-1 $\Delta$ VII splice variant (p42) has not been addressed. Therefore, we studied the functional effects of p42 Ets-1 in comparison to p51 Ets-1 expression in a well-characterized mouse fibroblast cell line. Furthermore, the specific role of Ets-1 was evaluated using mouse fibroblasts with a reduced Ets-1 expression caused by RNAi and compared to fibroblasts with a binding inhibition of the whole ETS transcription factor family by stably overexpressing the ETS DNA binding domain as transdominant-negative mutant. Our results demonstrate that $\mathrm{p} 42$ Ets-1 has quite different functions and target genes compared to p51 Ets-1 (e.g. TIMP-4, MMP-3, MMP-9, MMP-13). In some cases (e.g. in cytokine expression) p42 Ets-1 is a functional transcription factor which acts in the same manner as a transdominant-negative approach.
\end{abstract}

\section{Introduction}

Ets-1, the founding member of the ETS family, is expressed in endothelial cells during physiological and, more importantly, pathological conditions such as tumour vascularization and is proposed to play a role in angiogenesis (1-7). We previously showed that ets- 1 is expressed in stromal capillary endothelials and fibroblasts of several human carcinomas, in correlation with tumour vascularization and invasion (6-12). Ets-1 is also

Correspondence to: Dr Nicolas Wernert, Institute of Pathology, University of Bonn, P.O. Box 2120, D-53011 Bonn, Germany

E-mail: nicolas.wernert@ukb.uni-bonn.de

Key words: Ets-1, splice-variant, fibroblast, metalloproteinases, tissue inhibitors of metalloproteinases, cytokine expressed in epithelial carcinoma cells, though less frequently than in stromal cells $(6,7,9,10,13)$.

All members of the ETS transcription factor family share a specific DNA-binding domain composed of $\sim 80$ amino acids (ETS domain) (14) which mediates transactivation or repression of numerous target genes (15-22). Because of the high conserved ETS domain the ETS transcription factor members have overlapping specificities (23) and it is possible to block the effects of the whole ETS family by expressing an Ets transdominant-negative mutant in the cell (24).

In the full-length isoform of the Ets-1 transcription factor (p51 Ets-1), two inhibitory regions located on either side of the ETS domain associate together and regulate p51 Ets-1 affinity for DNA. In the absence of DNA, the N-terminal part of this region, coded by exon VII, interacts with the ETS domain and with the C-terminal region to create an autoinhibited conformation. When p51 Ets-1 is bound to DNA, the inhibitory $\alpha$ helix 1 is unfolded and the inhibitory module unpacked, this status correlates with a higher affinity for DNA (25-27). In p51 Ets-1, the domain encoded by exon VII contains four serine residues that are phosphorylated upon $\mathrm{Ca}^{2+}$ activation (28). This phosphorylation inhibits DNA binding by reinforcing the autoinhibition $(28,29)$. Thus, the domain encoded by exon VII plays a central role in p51 Ets-1 as it is directly involved in the regulation of DNA binding and is target of second messenger pathways.

In human, mouse and rat, an Ets-1 variant that arises from the splicing of exon VII has been identified (p42 Ets-1) (30-33). This variant displays specific properties that are not shared by the full-length protein; it misses the essential serine residues and is not subject to $\mathrm{Ca}^{2+}$-dependent phosphorylation and inhibition of DNA $(28,29,34)$, moreover, p42 Ets-1 induces colon cancer cell apoptosis (35) and overexpression of caspase-1/ICE in these cells while p51 Ets-1 does not (36). The role of p42 Ets-1 has not been extensively studied and several fundamental questions concerning its function and target genes remain even if it has been shown that p42 Ets-1 is a functional transcription factor with a quite different DNA recognition capacity from that of p51 Ets-1 (30).

In the present work we have studied the functional effects of p42 Ets-1 in comparison to p51 Ets-1 expression in mouse 
fibroblasts. Furthermore, the specific role of Ets-1 was evaluated using mouse fibroblasts with a reduced Ets-1 expression caused by RNAi and compared to fibroblasts with a binding inhibition of the whole ETS transcription factor family by stably over-expressing the ETS-DNA binding domain as transdominant-negative mutant.

\section{Materials and methods}

Plasmid construction. The mouse ets- 1 coding sequence was amplified by PCR using mRNA derived from mouse fibroblasts with the deoxyoligonucleotides 5'-ATGAAGGCGGC CGTCGATCTCAAGCCG-3' and 5'-CCATGACAAGTCAG CATCCGGCTTTACATC-3'. The amplified fragment was inserted into the pcDNA3.1 vector (Invitrogen) in sense and anti-sense orientation resulting in pcDNA3.1m-ets- 1 and pcDNA3.1m-ets- 1 inverse, respectively. The DNA binding domain of ets-1 was amplified by PCR and the amplified fragment was inserted into the pEGFP-C vector (Clontech). The plasmid coding for ets-1 splice variant $\Delta$ VII was kindly provided by F. Soncin (30). All constructs were verified by sequencing.

Cell culture and stable transfections. NIH3T3 cells were cultured in Dulbecco's modified Eagle's medium (DMEM, Invitrogen) supplemented with antibiotics and 10\% heatinactivated fetal calf serum (FCS, Invitrogen). The plasmids were transfected into the cells by the calcium phosphate method $(37,38)$. Twenty-four hours after transfection, selection was started using $400 \mu \mathrm{g} / \mathrm{ml} \mathrm{G} 418$ (Life Technologies).

Preparation of nuclear extract and Western blotting. Nuclear extracts were prepared as described previously (39). Briefly, $5 \times 10^{6}$ cells were washed twice in $10-\mathrm{ml}$ ice-cold phosphatebuffered saline (PBS, Invitrogen), resuspended in $500 \mu 1$ buffer A [10 mM HEPES (pH 7.9), $1.5 \mathrm{mM} \mathrm{MgCl}_{2}, 10 \mathrm{mM}$ $\mathrm{KCl}, 0.5 \mathrm{mM}$ DTT ( $\mathrm{pH}$ 7.9)] with protease inhibitor cocktail (Roche Diagnostics) and incubated on ice for $15 \mathrm{~min}$. NP-40 was added to a final concentration of $0.5 \%$, and the cells were vortexed for $10 \mathrm{sec}$. The nuclei were collected by centrifugation $(6500 \mathrm{x} \mathrm{g}$ for $20 \mathrm{~min})$ and resuspended in $150 \mu \mathrm{l}$ buffer C [20 mM HEPES (pH 7.9), $1.5 \mathrm{mM} \mathrm{MgCl}_{2}, 420 \mathrm{mM} \mathrm{NaCl}$, $0.2 \mathrm{mM}$ EDTA, $25 \%$ (v/v) glycerol) with protease inhibitors. The nuclear suspension was stirred vigorously on ice for $30 \mathrm{~min}$. The sample was centrifuged at $13000 \mathrm{x} \mathrm{g}$ for $10 \mathrm{~min}$, and aliquots of the supernatant were frozen immediately on dry ice. The protein concentration was determined by Bradford assay (BioRad) prior to Western blotting. Total protein $(12.5 \mu \mathrm{g})$ was analysed by $10 \%$ SDS-polyacrylamide gel electrophoresis and transferred onto nitrocellulose (Bio-Rad). After blocking with 5\% non-fat dry milk in PBS (Invitrogen) for $2 \mathrm{~h}$ at room temperature, filters were incubated in TBS-T (50 mM Tris, $150 \mathrm{mM} \mathrm{NaCl}, 0.1 \%$ Tween-20, pH 7.5) and with anti-Ets-1 rabbit polyclonal serum (1:1000; Transduction Laboratories), then with the horseradish peroxidase-conjugated secondary antibody (1:5000; Amersham Biosciences). Antibodies were detected using ECL reagents (Amersham Biosciences).

Luciferase reporter gene assay. The TIMP-4/pGL2 plasmid (3 $\mu \mathrm{g}$ per well) bearing the luciferase gene under the control of the TIMP-4 promoter was transfected into the cells (1x10 6 cells per $35-\mathrm{mm}$ well) as described above, together with $3 \mu \mathrm{g}$ of pCH110 (Amersham Pharmacia) normalization vector. Luciferase and $\beta$-galactosidase activity were measured using a luminometer (Berthold) according to manufacturer's instructions (Promega and Tropix, respectively).

Soft agar assay. Cells (10 $0^{5}$ cells in DMEM, 20\% FCS) were mixed with an equal volume of $0.8 \%$ agarose (FMC BioProducts) and poured onto a bed of $1.4 \%$ agarose in culture plates. The plates were fed every 3 days with $2 \mathrm{ml}$ of DMEM containing $10 \%$ FCS. The plates were observed for colony formation.

Invasion assay. Invasion assays were performed in Matrigel Chambers (Becton-Dickinson) containing polyethylene membranes with $8-\mu \mathrm{m}$ pore size coated with basement membrane (Matrigel, Becton-Dickinson). NIH3T3 cells were harvested by trypsinization, resuspended in DMEM at a density of $5 \times 10^{4}$ cells $/ \mathrm{ml}$ and $2.5 \times 10^{4}$ cells were plated in the upper compartment of the chamber. After incubation at $37^{\circ} \mathrm{C}$ for $22 \mathrm{~h}$ filters were removed. Cells adhering to the lower surface were fixed, stained with Hemacolor ${ }^{\circledR}$ (Merck) and counted.

Cytokine determination. Cell density was adjusted to 1000 cells/ml in DMEM supplemented with $0.5 \%$ penicillinstreptomycin and $0.5 \%$ FCS. Part of the adjusted experimental culture $(1 \mathrm{ml})$ was added to each well of a 24 -well-plate (1000 cells/well). The plates were incubated at $37^{\circ} \mathrm{C}$ with $5 \%$ $\mathrm{CO}_{2}$ in a humidified atmosphere for $24 \mathrm{~h}$. Supernatants from wells of the same cell line were pooled and centrifuged at $4000 \mathrm{rpm}$ for $10 \mathrm{~min}$ at room temperature. Clear supernatants were used for the cytokine determination. Measurement of cytokines [IL-1 $\alpha$, IL-1 $\beta$, IL-2, IL-3, IL-4, IL-5, IL-6, IL-10, IL-12 (p40), IL-12 (p70), IL-17, G-CSF, GM-CSF, IFN- $\gamma$, $\mathrm{KC}, \mathrm{MIP}-1 \alpha$, RANTES and TNF- $\alpha$ ] were performed with the BIO-PLEX-System (Bio-Rad) according to the manufacturer's instructions.

RNA isolation and cDNA synthesis. Total cellular RNA was extracted from cell monolayers by the RNeasy kit (Qiagen). Generation of cDNAs by reverse transcriptase was performed in $10-\mu \mathrm{l}$ reaction volume containing $2 \mu \mathrm{g}$ of total cellular RNA, $1 \mu \mathrm{l}$ of dNTPs $(10 \mathrm{mM}), 1 \mu \mathrm{l}$ of oligo(dT) $)_{12-18}$ primer $(10 \mathrm{mM})$, and RNAse-free water. After incubation at $65^{\circ} \mathrm{C}$ for $5 \mathrm{~min}$ the reaction mixture was placed on ice for $1 \mathrm{~min}$. Then $2 \mu \mathrm{l}$ of $10 \mathrm{X}$ RT buffer (Invitrogen), $4 \mu 1 \mathrm{MgCl}_{2}(25 \mathrm{mM}), 2 \mu 1$ of $0.1 \mathrm{M}$ DTT, and $1 \mu \mathrm{l}$ RNAseOut ${ }^{\mathrm{TM}}$ recombinant RNAse inhibitor (Invitrogen) was added. After incubation at $42^{\circ} \mathrm{C}$ for 2 min 1 $\mu 1$ of Superscript II reverse transciptase (50 U/ $\mu \mathrm{l}$; Invitrogen) was added for the transcription at $42^{\circ} \mathrm{C}$ for $1 \mathrm{~h}$. Inactivation of the enzyme was performed at $70^{\circ} \mathrm{C}$ for $15 \mathrm{~min}$. In the last step RNA was removed by addition of $1 \mu \mathrm{RNAseH}$ and incubated at $37^{\circ} \mathrm{C}$ for $20 \mathrm{~min}$.

$P C R$. For analysis of gene expression polymerase chain reaction (PCR) amplifications were performed using GeneAmp PCR System 9700 (Applied Biosystems). All primers were synthesised by TIB MolBiol and the primer sequences are summarized in Table I. PCR amplification of cDNA was performed in a reaction containing $2.5 \mu \mathrm{l}$ of $10 \mathrm{X}$ polymerase buffer, $1.5 \mathrm{mM}$ $\mathrm{MgCl}_{2}, 0.2 \mathrm{mM}$ each desoxynucleoside triphosphate, $25 \mathrm{pmol}$ 
Table I. Primer used for RT-PCR.

\begin{tabular}{lll}
\hline Gene & \multicolumn{1}{c}{ Forward primer } & \multicolumn{1}{c}{ Reverse primer } \\
\hline RPL-13 A & 5'-TACGCTGTGAAGGCATCAAC-'3 & 5'-CACCATCCGCTTTTTCTTGT-'3 \\
Ets-1 & 5'-CGATCTCAAGCCGACTCTCA-'3 & 5'-GAAGCTGGGCTCTGAGAACTC-'3 \\
Ets-1 (exonVII) & 5'-CCCTCTCCAGACAGACACCTTG-'3 & 5'-GCCACGGCTCAGTTTCTCAT-'3 \\
TIMP-1 & 5'-CATGGAAAGCCTCTGTGGATATG-'3 & 5'-AAGCTGCAGGCACTGATGTG-'3 \\
TIMP-2 & 5'-CCAGAAGAAGAGCCTGAACCA-'3 & 5'-GTCCATCCAGAGGCACTCATC-'3 \\
TIMP-3 & 5'-GGCCTCAATTACCGCTACCA-'3 & 5'-CTGATAGCCAGGGTACCCAAAA-'3 \\
TIMP-4 & 5'-TGCAGAGGGAGAGCCTGAA-'3 & 5'-GGTACCCATAGAGCTTCCG-'3 \\
MMP-2 & 5'-GTACTGGGTCTATTCTGCTAG-'3 & 5'-CACTTCATTGTATCTCCAG-'3 \\
MMP-3 & 5'-ACGAGGGCACGAGGAGCTAGC-'3 & 5'-GGGTCAAATTCCAACTGAGAAG-'3 \\
MMP-9 & 5'-GTTCCCACTTACTATGGAAAC-'3 & 5'-CGTGCTCCGTGTAGAGTCTC-'3 \\
MMP-13 & 5'-GAATGGTTATGACATTCTGGA-'3 & 5'-GATACTGTATTCAAACTGTATGG-'3 \\
Cadherin-11 & 5'-TTGGCTCTGAACAGCTGAAA-'3 & 5'-CCCAAGTCAGCTCACAGTCA-'3 \\
Fibulin 5 & 5'-GTGAACGAGTGCGAAACTGA-'3 & 5'-CTGGCAGCTTCGGTTATCAT-'3 \\
\hline
\end{tabular}

Table II. PCR conditions used for amplification with 25 cycles of denaturation, annealing and extension.

\begin{tabular}{|c|c|c|c|}
\hline & Denaturation & Annealing & Extension \\
\hline$r p L 13 A$ & $94^{\circ} \mathrm{C}$ for $30 \mathrm{sec}$ & $66^{\circ} \mathrm{C}$ for $30 \mathrm{sec}$ & $72^{\circ} \mathrm{C}$ for $30 \mathrm{sec}$ \\
\hline ets-1 & $94^{\circ} \mathrm{C}$ for $30 \mathrm{sec}$ & $65^{\circ} \mathrm{C}$ for $30 \mathrm{sec}$ & $72^{\circ} \mathrm{C}$ for $60 \mathrm{sec}$ \\
\hline ets-1 (ExonVII) & $94^{\circ} \mathrm{C}$ for $30 \mathrm{sec}$ & $65^{\circ} \mathrm{C}$ for $30 \mathrm{sec}$ & $72^{\circ} \mathrm{C}$ for $60 \mathrm{sec}$ \\
\hline timp 1 & $94^{\circ} \mathrm{C}$ for $30 \mathrm{sec}$ & $60^{\circ} \mathrm{C}$ for $30 \mathrm{sec}$ & $72^{\circ} \mathrm{C}$ for $30 \mathrm{sec}$ \\
\hline timp 2 & $94^{\circ} \mathrm{C}$ for $30 \mathrm{sec}$ & $60^{\circ} \mathrm{C}$ for $30 \mathrm{sec}$ & $72^{\circ} \mathrm{C}$ for $30 \mathrm{sec}$ \\
\hline timp 3 & $94^{\circ} \mathrm{C}$ for $30 \mathrm{sec}$ & $60^{\circ} \mathrm{C}$ for $30 \mathrm{sec}$ & $72^{\circ} \mathrm{C}$ for $30 \mathrm{sec}$ \\
\hline timp 4 & $94^{\circ} \mathrm{C}$ for $30 \mathrm{sec}$ & $60^{\circ} \mathrm{C}$ for $30 \mathrm{sec}$ & $72^{\circ} \mathrm{C}$ for $30 \mathrm{sec}$ \\
\hline mmp 2 & $94^{\circ} \mathrm{C}$ for $30 \mathrm{sec}$ & $57^{\circ} \mathrm{C}$ for $30 \mathrm{sec}$ & $72^{\circ} \mathrm{C}$ for $30 \mathrm{sec}$ \\
\hline mmp 3 & $94^{\circ} \mathrm{C}$ for $30 \mathrm{sec}$ & $65^{\circ} \mathrm{C}$ for $30 \mathrm{sec}$ & $72^{\circ} \mathrm{C}$ for $30 \mathrm{sec}$ \\
\hline mmp 9 & $94^{\circ} \mathrm{C}$ for $30 \mathrm{sec}$ & $64^{\circ} \mathrm{C}$ for $30 \mathrm{sec}$ & $72^{\circ} \mathrm{C}$ for $30 \mathrm{sec}$ \\
\hline mmp 13 & $94^{\circ} \mathrm{C}$ for $30 \mathrm{sec}$ & $59^{\circ} \mathrm{C}$ for $30 \mathrm{sec}$ & $72^{\circ} \mathrm{C}$ for $30 \mathrm{sec}$ \\
\hline Cadherin-11 & $94^{\circ} \mathrm{C}$ for $30 \mathrm{sec}$ & $56^{\circ} \mathrm{C}$ for $30 \mathrm{sec}$ & $72^{\circ} \mathrm{C}$ for $30 \mathrm{sec}$ \\
\hline Fibulin 5 & $94^{\circ} \mathrm{C}$ for $30 \mathrm{sec}$ & $56^{\circ} \mathrm{C}$ for $30 \mathrm{sec}$ & $72^{\circ} \mathrm{C}$ for $30 \mathrm{sec}$ \\
\hline
\end{tabular}

5 ' primer and 25 pmol 3' primer, $0.1 \mu \mathrm{l}(0.5 \mathrm{U})$ Taq DNA polymerase, $0.5 \mu 1 \mathrm{cDNA}$ template and sterile RNAse-free water to a total volume of $25 \mu \mathrm{l}$. All PCR reagents were from Invitrogen.

First of all amplification of a house-keeping gene, the constitutively expressed ribosomal protein L13A (rpL13A) (40), was undertaken to monitor the quality of the RNA extraction, the cDNA synthesis and to ensure that equivalent amounts of cDNA were used in all PCR amplifications. All PCR reactions were preceded by a denaturation step at $94^{\circ} \mathrm{C}$ for $1 \mathrm{~min}$ followed by 25 cycles of denaturation, annealing and extension; PCR conditions for the different cDNAs are shown in Table II. Every PCR reaction was finished by a final elongation step at $72^{\circ} \mathrm{C}$ for $10 \mathrm{~min}$. All PCR products were analysed by separation on a $2 \%$ agarose gel stained with ethidium bromide.

Immunohistochemistry. Cells grown in $1 \mathrm{~cm}^{2}$ culture chambers (Nunc) were rinsed once with PBS (Invitrogen), twice with 70\% ethanol and fixed in a mixture of ice cold methanol and ethanol [1:2 (v:v)] at $4^{\circ} \mathrm{C}$ for $20 \mathrm{~min}$. After washing twice with PBS (Invitrogen) cells were stained with antibodies directed against integrin- $\beta 2$; 1:200 dilution (41), Santa Cruz Biotechnology. The cells were incubated with the primary antibody at $37^{\circ} \mathrm{C}$ for $60 \mathrm{~min}$. Detection of the primary antibody was carried out by using the LSAB-peroxidase-system (Dako) according to the manufacturer's instructions.

\section{Results}

Ets-1 expression and activity. The well characterized NIH3T3 cell line was used to monitor the effects of Ets-1 and the role of the two different splice variants in fibroblasts. Four stable NIH3T3 cell lines were established following transfection with either an Ets-1 p51, an Ets-1 p51-anti-sense, an Ets-1 p42 or an Ets-1-DNA binding domain (Ets-1-DB) expression 
A
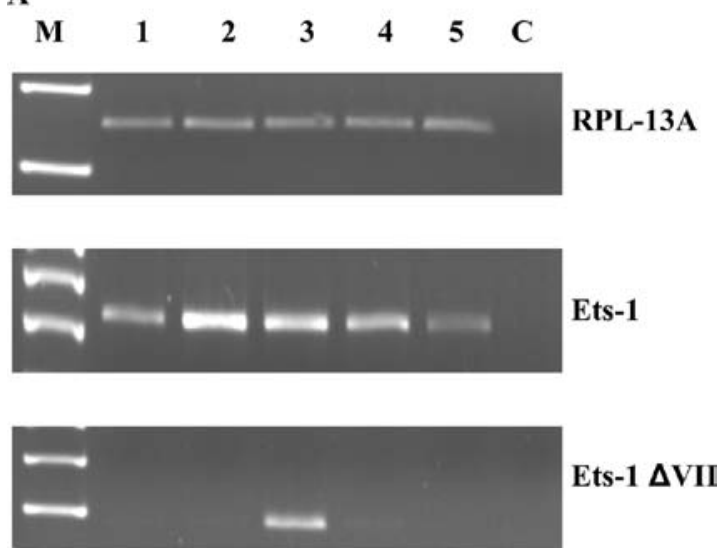

B

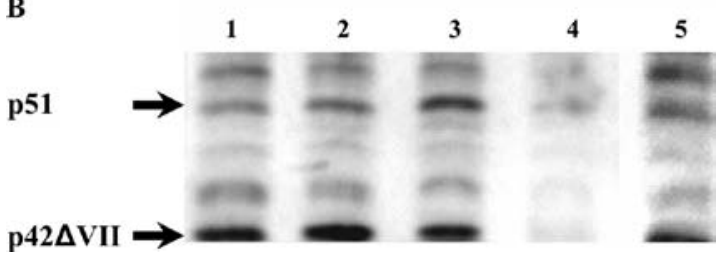

Figure 1. RT-PCR analysis (A) and Western blotting (B) showing expression of the different Ets-1 constructs. (A) Expression of transcripts was analysed with specific primers for Ets-1 and Ets-1 $\Delta$ VII in NIH3T3 cells (lane 1), 3T3Ets-1 cells (lane 2), 3T3-Ets-1 $\Delta$ VII cells (lane 3), Ets-1-DB overexpressing cells (lane 4) and 3T3-inverse cells (lane 5). The negative control (C) for any PCR is shown at the end of every line. The house-keeping gene rpL-13A was amplified in order to monitor RNA quality and cDNA synthesis and to ensure that equivalent amount of cDNA were used in all PCR amplifications. Fragment sizes were evaluated with a PCR-marker (M); gene specific products are 251-bp for rpL-13A, 536-bp for Ets-1 and 268-bp for Ets-1 $\Delta$ VII. (B) Western blotting showing expression of full-length Ets-1 protein (p51) and of Ets-1 splice-variant lacking exon VII (p42) in NIH3T3 mock-transfected cells (lane 1), 3T3-Ets-1 $\Delta$ VII cells (lane 2), 3T3-Ets-1 cells (lane 3), 3T3-inverse cells (lane 4) and wild-type NIH3T3 cells (lane 5).

vector. Full-length Ets-1-overexpressing (3T3-Ets-1) and -under expressing (3T3-inverse) cell lines as well as Ets-1 p42 (3T3-Ets-1 $\Delta$ VII) and Ets-1-DB overexpressing cell lines were selected from the pooled population of transfected cells, in order to avoid clonal variations. The resulted cell lines were first analysed for Ets-1 transcripts by RT-PCR and compared to wild-type NIH3T3 cells (Fig. 1A). As expected for the ubiquitously expressed transcription factor, Ets-1 transcripts were found in NIH3T3 wild-type cells but only the full-length transcript was detected. In the 3T3-Ets-1 cell line a higher expression level of full-length Ets-1 and in the 3T3-Ets-1 $\Delta$ VII cell line transcripts coding for the splice variant Ets- $1 \Delta \mathrm{VII}$ in addition to the full-length transcripts were found. In the Ets-1-DB overexpressing cell line Ets-1 full-length transcripts can be detected in the same range as in wild-type cells, because endogenous Ets-1 level is not affected on the RNA level by the Ets-1-DB expression. In contrast a significantly reduced level of Ets-1 transcripts was found in the 3T3-inverse cell line as expected for this RNAi-based strategy.

The established cell lines and the parental cells were also analysed on the protein level by Western blotting with an ETS-1-specific antibody (Fig. 1B). An upregulation of Ets-1 full-length protein (p51; lane 3) and of Ets-1 splice-variant lacking exon VII (p42; lane 2) in the stable-transfected NIH3T3

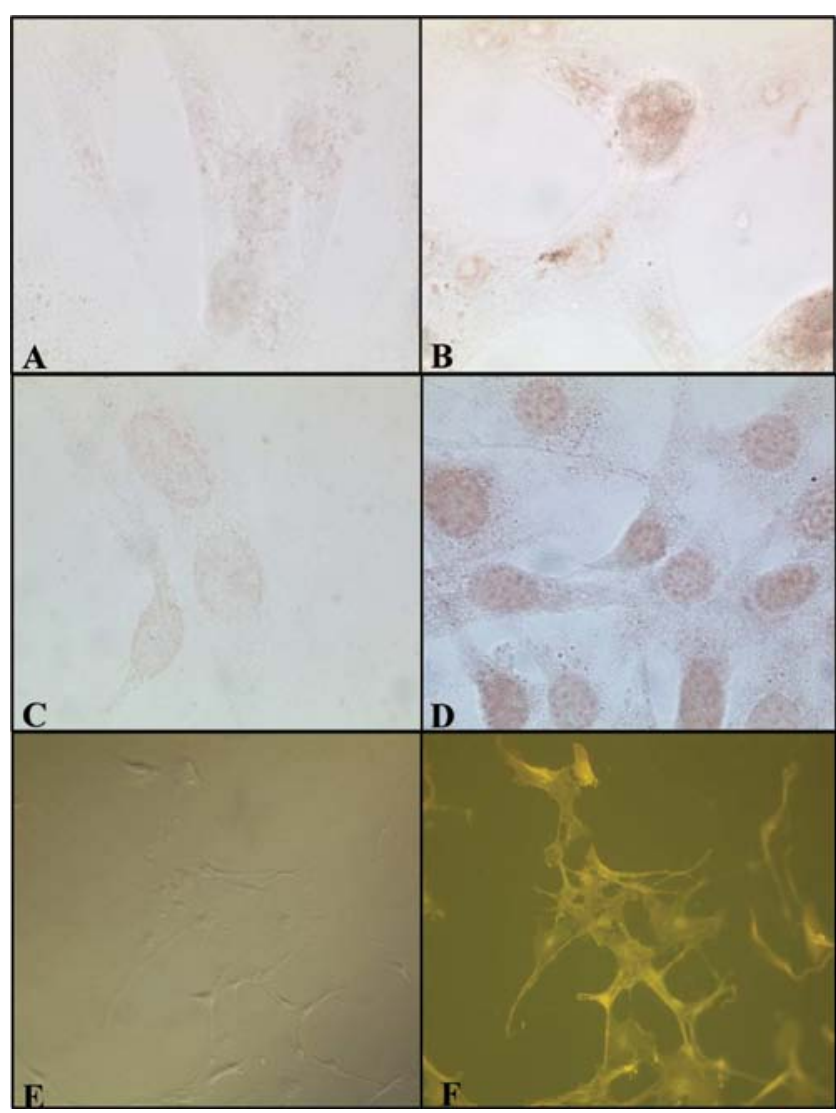

Figure 2. Localisation of the different Ets-1 constructs in the cells. Localisation and expression of Ets-1 full-length (B) and Ets-1 $\Delta$ VII (D) was analysed in 3T3-Ets-1 and 3T3-Ets-1 $\Delta$ VII cells, respectively, by detection of the fused tag (100-fold magnification) in comparison to controls with wild-type NIH3T3 cells (A and C). Localisation and expression of Ets-1-DB-EGFP fusion protein (E, transmitted light; F, fluorescence light) in Ets-1-DB overexpressing cells was analysed by immunofluorescence (20-fold magnification).

cell lines was found. The inverted Ets-1 sequence (lane 4) effectively abrogates both $\mathrm{p} 51$ and $\mathrm{p} 42$ expression. It is evident that the mock-transfected cells (lane 1) are identical with NIH3T3 wild-type cells (lane 5). The expression of Ets-1-DB in the established cell line could not be demonstrated by Western blotting due to the fact that the antibody recognized an epitope outside the Ets-1-DB DNA sequence.

In the next step we addressed the question of protein localisation in the cells. For this purpose the different tags fused to the transgenes are used for immunohistochemical analysis (Fig. 2). The nuclear expression of the overexpressed p51 and p42 Ets-1 was visualized by using antibodies against the V5 and the HA epitope, respectively. For demonstrating the expression of the Ets-1-DB the fluorescence of the fused EGFP was used by fluorescence microscopy. These observations suggest that the properties of the established 3T3 cell lines corresponded to the strategy that was adopted to produce them.

In order to evaluate the effect of the different Ets-1 expression levels and splice variants in fibroblasts cellular behaviour was accessed in different assays. The proliferation rates of 3T3-Ets-1, 3T3-Ets-1 $\Delta$ VII, 3T3-inverse and wild-type NIH3T3 cells were found to be comparable (Fig. 3). In the case of 3T3 Ets-1-DB increased cell growth was observed; 


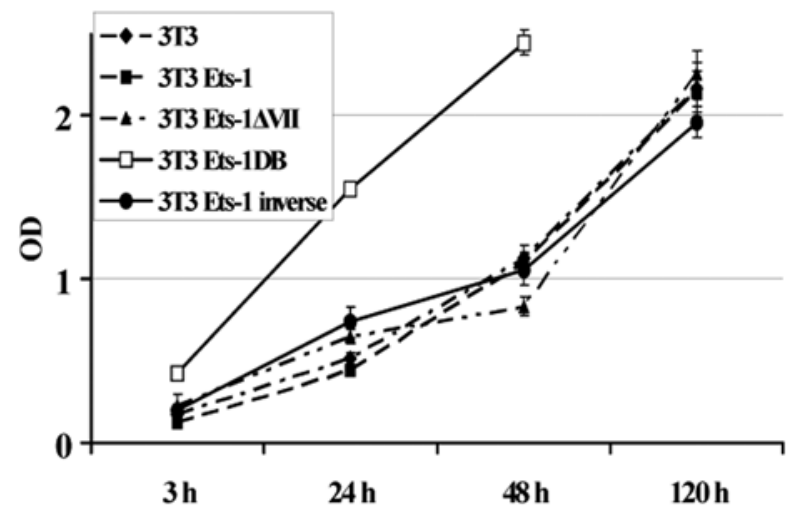

Figure 3. Cell proliferation rates. Proliferation rates of the different cell lines were determined by a modified MTT-assay during $120 \mathrm{~h}$. The mean value of three independent experiments is shown.

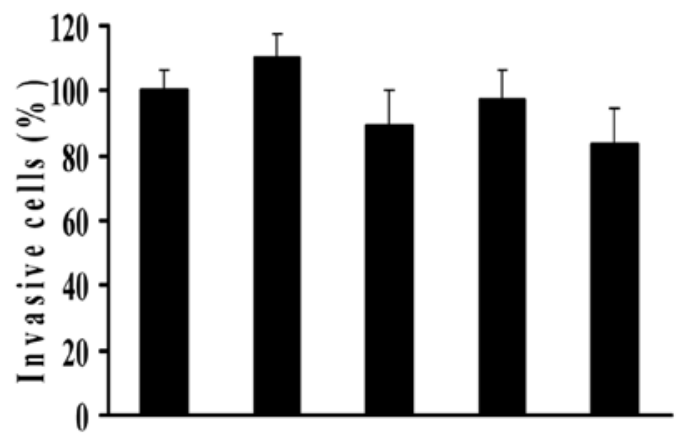

3T3 3T3-Ets- 3T3-Ets- 3T3-Ets- 3T3-

$$
1 \quad 1 \Delta \mathrm{VII} \quad 1 \mathrm{DB} \text { inverse }
$$

Figure 4. Invasive behaviour of the different cell lines. Cells were plated in the upper compartment of Matrigel Chambers containing polyethylene membranes with 8 -mm pore size coated with basement membrane. After incubation at $37^{\circ} \mathrm{C}$ for $22 \mathrm{~h}$, the filters were removed and the cells adhering to the lower surface were fixed, stained and counted. The mean value of three independent experiments is shown.

after $48 \mathrm{~h}$ the cells were confluent and after $120 \mathrm{~h}$ they were detached (Fig. 3).

Next we compared the invasive activity of the different cell lines in a Matrigel invasion assay. NIH3T3 and 3T3 Ets-1-DB cells had a comparable invasive behavior, while 3T3-Ets-1 cells showed a slight increase in invasive migration through the Matrigel (Fig. 4). In contrast 3T3-Ets-1 $\Delta$ VII and 3T3-inverse cells showed a decreased invasive behaviour. The invasive migration was decreased $>25 \%$ in 3T3-inverse cells and $\sim 20 \%$ in 3T3-Ets-1 $\Delta$ VII cells compared to 3T3-Ets-1 cells. These results showing that p51 Ets-1 overexpression increase the migrating and invasive properties of 3T3 cells, suggested that full-length Ets-1 had a transforming effect on these cells. In contrast p42 Ets-1 overexpression decreased the migration and invasive properties of 3T3 cells and the effects are comparable with a reduction of full-length Ets-1 expression in 3T3 cells.

Migration and motility of cells requires a coordinated swap between cell detachment and attachment, we therefore examined the influence of Ets-1 expression on the attachment of 3T3 cells. As illustrated in Fig. 5, differences in attachment of the different cell lines were observed $2.5 \mathrm{~h}$ after seeding the cells

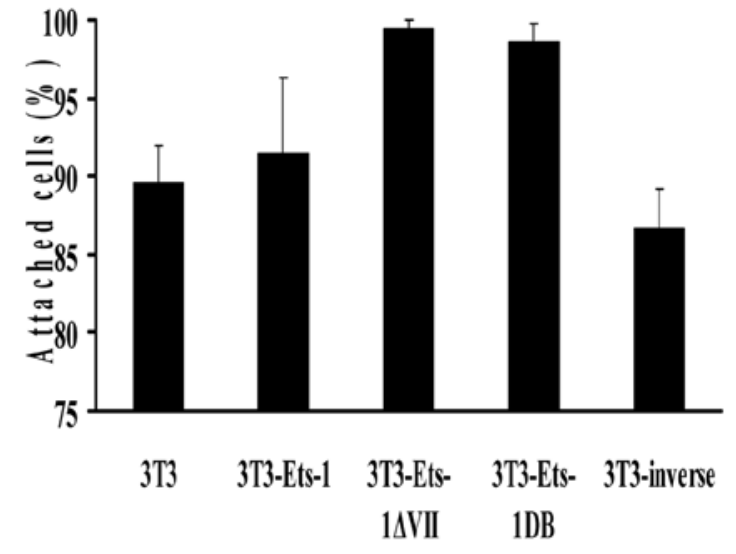

Figure 5. Attachment of the different cell lines. Cells $\left(10^{6}\right.$ per well) were seeded into $10 \mathrm{~cm}^{2}$ culture wells and incubated at $37^{\circ} \mathrm{C}$. After $2.5 \mathrm{~h}$, living cells in the supernatants were counted. The mean value of four independent experiments is shown.

into the wells. Nearly $90 \%$ of the NIH3T3 cells and $92 \%$ of the 3T3-Ets-1 cells had attached to the plastic surface while $>98 \%$ of 3T3-Ets-1 $\Delta$ VII and 3T3 Ets-1-DB cells were detected after the same time, but $<87 \%$ of the 3 T3-inverse cells had attached to the plastic surface. This suggests that expression of p42 Ets-1 as well as the transdominant negative approach favours slightly 3T3 cell adhesion.

In order to investigate further this point, we analyzed the influence of Ets-1 on contact inhibition and clonal growth of 3T3 cells using soft-agar assay. As shown in Fig. 6 3T3-Ets-1 cells showed the strongest capability for colony formation of the 3T3 cell lines studied. Notably 3T3 Ets-1-DB and 3T3-invers cells were unable to grow in an anchorage-independent way. Compared to NIH3T3 cells the 3T3-Ets-1 cells have a slightly increased and the $3 \mathrm{~T} 3$ Ets-1 $\Delta$ VII cells a slightly reduced growing capacity.

The observed differences in migration, clonogenicity and anchorage-independent growth between the different cell lines prompted us to analyse the effect of Ets-1 expression on the expression levels of several integrin receptors. Ets-1 expression did not affect the levels of integrin- $\beta 4$ (CD104), integrin- $\alpha 6$ (CD49f), integrin- $\alpha 3 \beta 1$ (CD49c) or integrin- $\beta 3$ (CD61) (data not shown). However, we observed a strong induction of integrin- $\beta 2$ (CD18) expression in 3T3-Ets-1 and 3T3-Ets-1 $\Delta$ VII particularly when compared to NIH3T3 cells while expression was reduced in 3T3 Ets-1-DB and undetectable in 3T3-inverse cells (Fig. 7).

Another reason for the observed differences in migration, clonogenicity and attachment between the different cell lines could be based on the cytokine expression. Therefore, we addressed the expression pattern of cytokines in the different fibroblast cell lines (Fig. 8). IL-1 $\beta$ expression was comparable in wild-type 3T3 and 3T3-Ets-1 cells. The IL-1 $\beta$ expression was increased 5- to 6-fold in 3T3-Ets-1 $\Delta$ VII and 3T3 Ets-1-DB cells. IL-10, IFN- $\gamma$ and IL-12 (p70) expression were nearly the same in all cell lines. TNF- $\alpha$ expression was slightly increased in 3T3-Ets-1 cells compared to the wild-type cells and significantly induced in 3T3-Ets-1 $\Delta$ VII and 3T3 Ets-1-DB cells. IL-1 $\alpha$ was only detected in 3 T3 Ets-1-DB cells at a very low level. Again the expression of MIP-1 $\alpha$ was the same in 


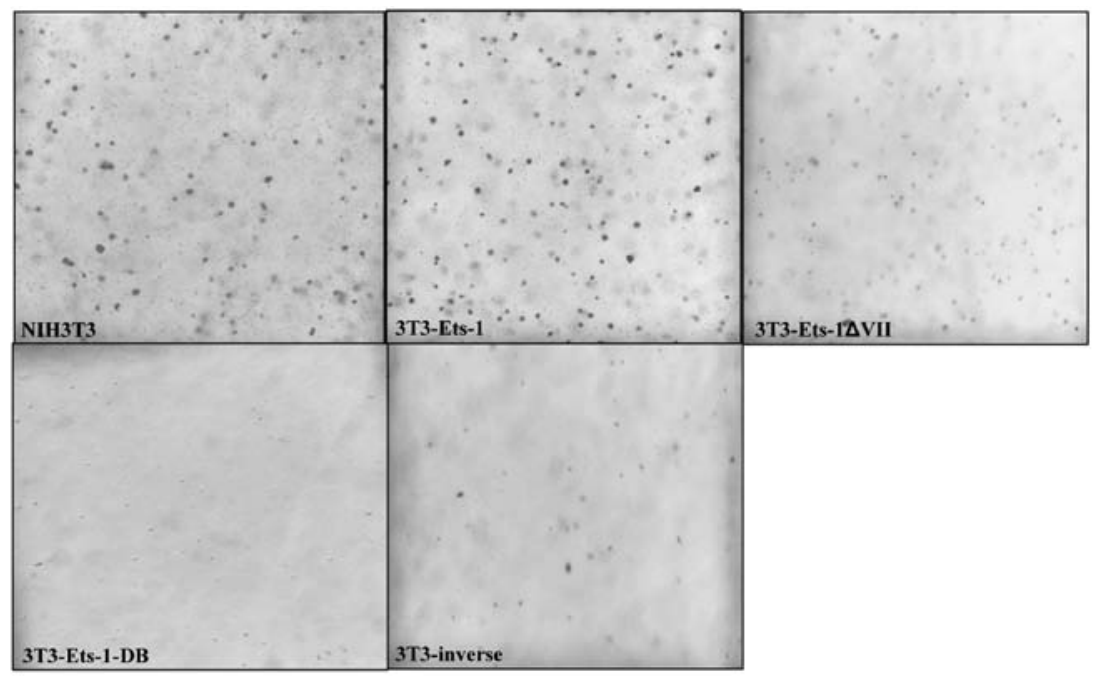

Figure 6. Anchorage-independent growth of the different cell lines (soft-agar assay). Cells (10 in DMEM, 20\% FCS) were mixed with an equal volume of $0.8 \%$ agarose and poured onto a bed of $1.4 \%$ agarose in culture plates. The culture medium was changed every 3 days and colony formation monitored (day 47 , 43.75-fold magnification).

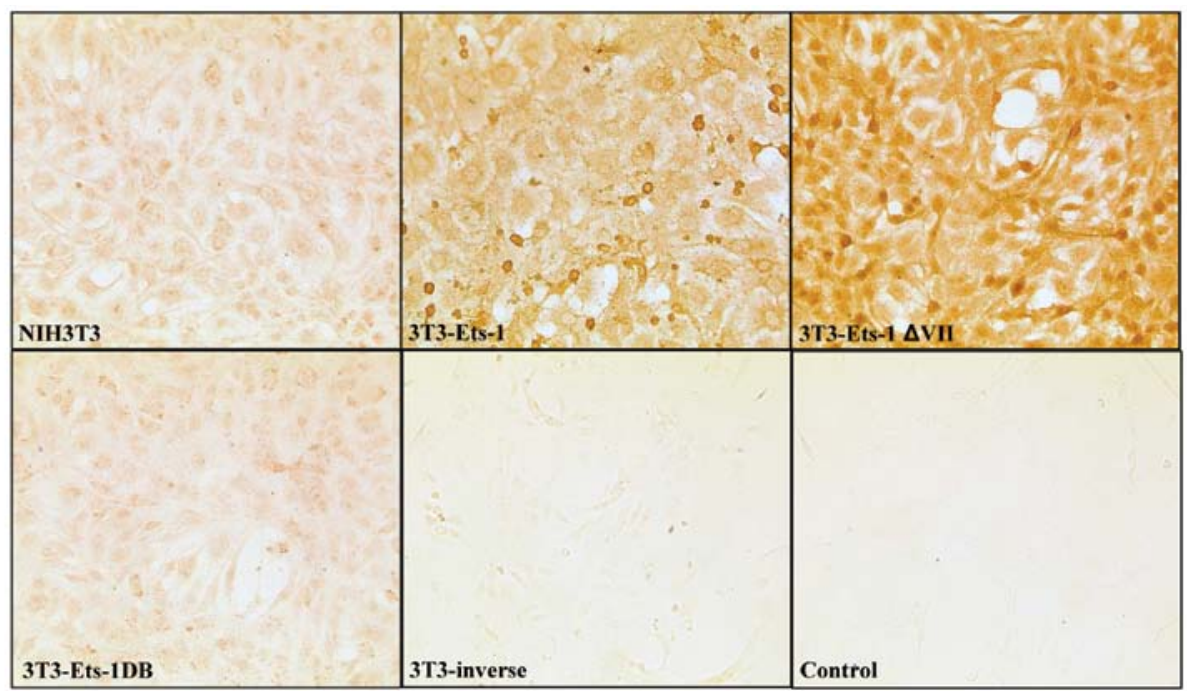

Figure 7. Expression of integrin $\beta 2$ in the different cell lines. Higher expression of integrin $\beta 2$ (CD18) correlates with Ets-1 full-length and Ets-1 $\Delta$ VII expression. The negative control (no $\mathrm{Ab}$ ) was incubated under the same conditions omitting primary antibody (50-fold magnification).

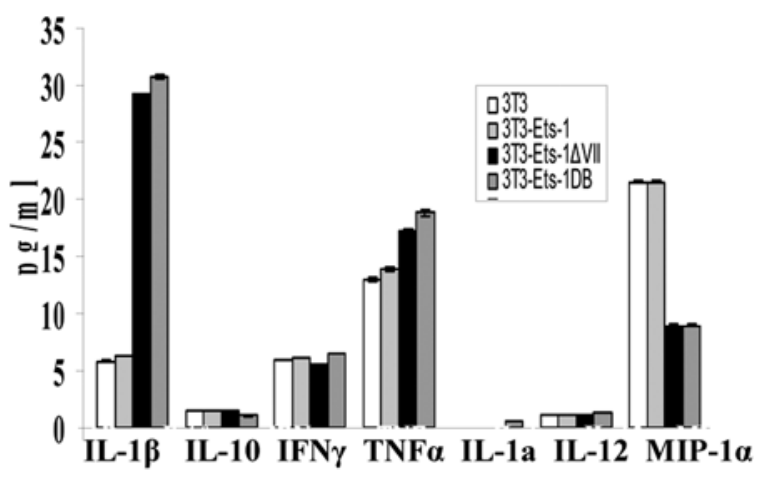

Figure 8. Cytokine expression profile of the different cell lines. From each cell line 1000 cells were incubated in wells of a 24 -well plate for $24 \mathrm{~h}$. Supernatants from 6 wells of the same cell line were pooled and centrifuged at $4000 \mathrm{rpm}$ for $10 \mathrm{~min}$ at room temperature. The amount of cytokines in this clear supernatant was determined with the BIO-PLEX-system. The mean value of two independent experiments is shown. wild-type 3T3 and 3T3-Ets-1 cells and strong reduced in 3T3-Ets-1 $\Delta$ VII and 3T3 Ets-1-DB cells. The cytokines IL-2, IL-3, IL-4, IL-5, IL-6, IL-12 (p40), IL-17, G-CSF, GM-CSF, $\mathrm{KC}$ and RANTES were not expressed in any of the cell lines (data not shown).

Finally the expression levels of further potential Ets- 1 target genes were addressed by RT-PCR analysis. Results of the PCR amplifications are shown in Fig. 9 and the quantification is summarized in Table III. The mRNA of the house-keeping gene rpL13A was amplified in all probes in the same range. Since it has been well established that genes of tissue inhibitors of metalloproteinases (TIMPs) are also among Ets-1 target genes we examined the expression of TIMP-1-4 in the different fibroblast cell lines. The expression of TIMP-1 was increased in all cell lines compared to NIH3T3 cells. TIMP-2 expression was increased in 3T3-Ets-1, 3T3-Ets-1 $\Delta \mathrm{VII}$ and particularly in 3T3 Ets-1-DB cells. TIMP-3 expression was 


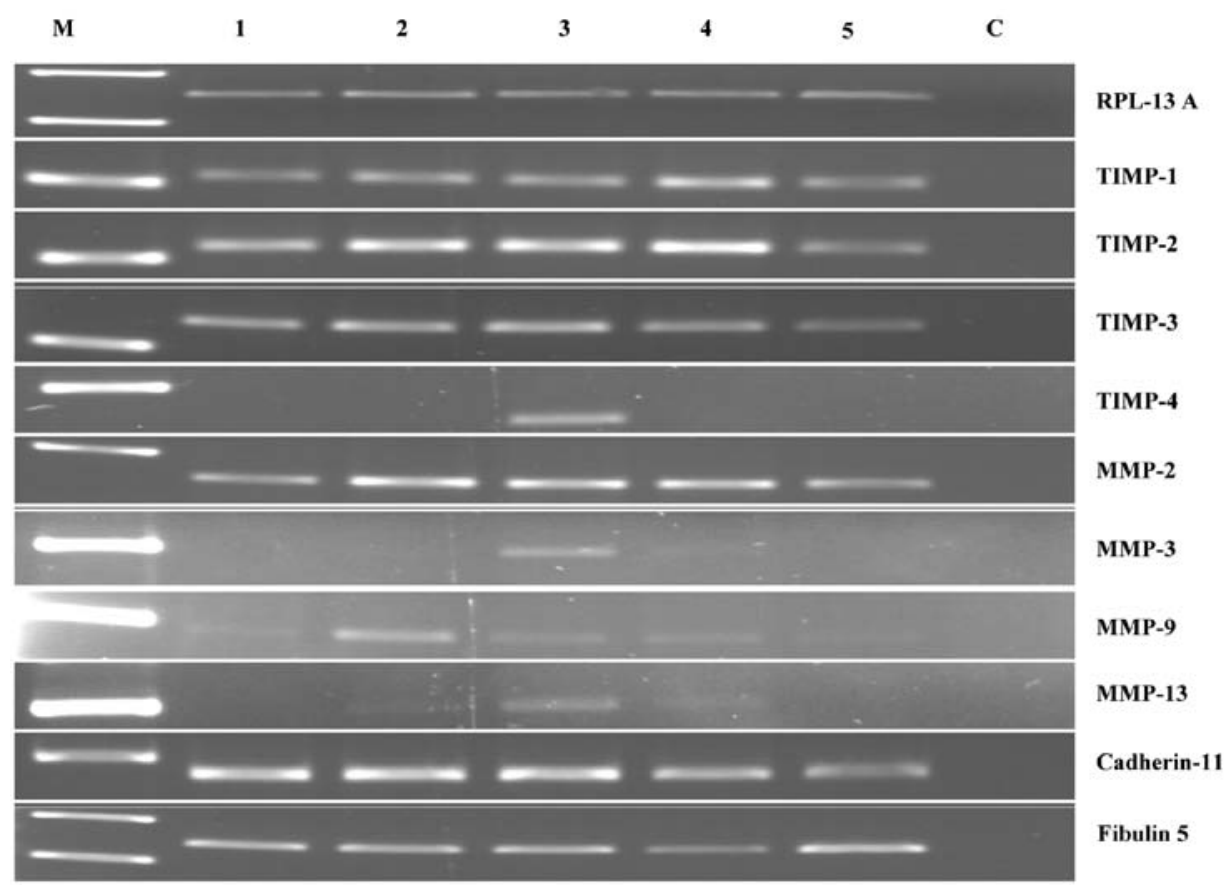

Figure 9. RT-PCR analysis of known Ets-1 target genes in the different cell lines. Determination of tissue inhibitors of metallomatrix proteinases and protease expression in NIH3T3 cells (lane 1), 3T3-Ets-1 cells (lane 2), 3T3-Ets-1 $\Delta$ VII cells (lane 3), Ets-1-DB overexpressing cells (lane 4) and 3T3-inverse cells (lane 5). The negative control (C) for any PCR is shown at the end of every line. Fragment sizes were evaluated with a PCR-marker (M); gene specific products are 251-bp for rpL13A, 108-bp for TIMP-1, 122-bp for TIMP-2, 135-bp for TIMP-3, 130-bp for TIMP-4, 166-bp for MMP-2, 280-bp for MMP-3, 188-bp for MMP-9, 295-bp for MMP-13, 274-bp for cadherin-11 and 239-bp for fibulin 5.

Table III. Quantification of the PCR products by densitometric measurement. ${ }^{\mathrm{a}}$

\begin{tabular}{lccccc} 
Gen & NIH3T3 & 3T3-Ets-1 & 3T3-Ets-1 $\Delta$ VII & 3T3-Ets-1-DB & 3T3-inverse \\
\hline RPL13A & 1.0 & 1.0 & 1.0 & 1.0 & 1.0 \\
Ets-1 & 1.0 & 1.5 & 1.2 & 1.0 & 0.8 \\
Ets-1 $\Delta 7$ & 0.0 & 0.0 & 1.7 & 0.0 & 0.0 \\
TIMP-1 & 1.0 & 1.6 & 1.3 & 1.6 & 1.6 \\
TIMP-2 & 1.0 & 1.1 & 1.2 & 1.2 & 0.7 \\
TIMP-3 & 1.0 & 1.1 & 1.2 & 0.8 & 0.7 \\
TIMP-4 & 0.0 & 0.0 & 1.5 & 0.0 & 0.0 \\
MMP-2 & 1.0 & 1.5 & 1.2 & 1.1 & 1.1 \\
MMP-3 & 0.0 & 0.0 & 1.2 & 0.0 & 0.0 \\
MMP-9 & 1.0 & 1.5 & 1.3 & 1.0 & 0.9 \\
MMP-13 & 0.0 & 1.0 & 1.3 & 0.0 & 0.0 \\
Cadherin-11 & 1.0 & 1.1 & 1.1 & 0.8 & 0.7 \\
Fibulin-5 & 1.0 & 1.2 & 1.0 & 0.6 & 1.3 \\
\hline
\end{tabular}

${ }^{a}$ The expression rate in NIH3T3 cells was set as one and the expression rate in the other cell lines was related to the control cells. If a gene was not expressed in NIH3T3 cells the induction rate was related to the background.

comparable in all 3T3 cell lines. The most striking difference between the cell lines concerned TIMP-4 expression. TIMP-4 was only expressed in the $3 \mathrm{~T} 3$-Ets-1 $1 \mathrm{VII}$ cells.

Metalloproteinases (MMPs) are among the best characterized Ets-1 target genes and therefore we examined the expression of MMP-2, MMP-3, MMP-9 and MMP-13.
MMP-2 expression was slightly increased in 3T3-Ets-1 cells. MMP-3 and MMP-13 expression was only detected in 3T3-Ets-1 $\Delta$ VII cells whereas all other cell lines are negative for MMP-3 as well as MMP-13. MMP 9 expression was strongly induced in 3T3-Ets-1 cells and slightly in 3T3-Ets-1 $\Delta$ VII cells. Cadherin-11 is slightly decreased in 3T3 Ets-1-DB 


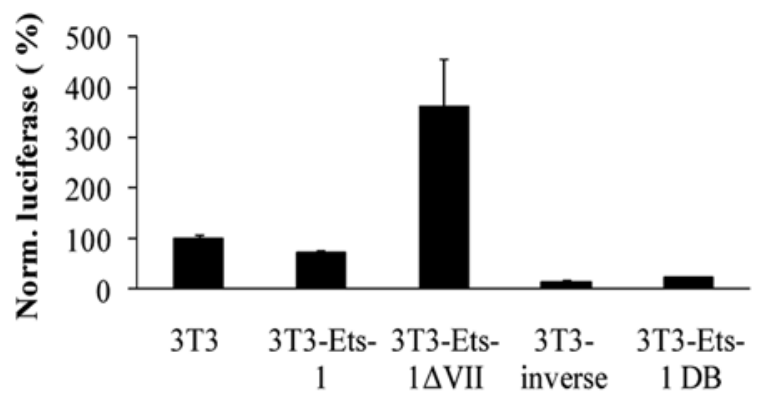

Figure 10. TIMP-4 driven luciferase expression in the different cell lines. In order to evaluate the transcriptional activity in regard to TIMP-4 expression in the different cell lines, a plasmid bearing the luciferase gene under the control of the TIMP-4 promoter was transiently transfected into the cells together with the pCH110 normalization vector. Luciferase and $\beta$-galactosidase activity were measured using a luminometer. The normalized luciferase activity measured in NIH3T3 cells was set as $100 \%$. The mean value of two independent experiments and measurements is shown.

and 3T3-inverse cells, whereas fibulin 5 is slightly decreased in 3T3 Ets-1-DB cells.

The surprising finding that TIMP-4 is only expressed in the 3T3-Ets-1 $\Delta$ VII cells was further evaluated with a reporter gene assay (Fig. 10). Therefore the different cell lines were transiently co-transfected with a plasmid coding for luciferase under the control of TIMP-4 promoter and a plasmid coding for $\beta$-galactosidase. The highest TIMP-4 promoter activity was observed in 3T3-Ets-1 $\Delta$ VII cells; in comparison to all other cell lines the differences were statistically significant at $\mathrm{P}<0.005$. In 3T3-inverse and 3T3 Ets-1-DB cells the TIMP-4 promoter activity was significant reduced compared to the NIH3T3 cells.

\section{Discussion}

Ets-1 expression has been associated with several aspects of embryonic development, including vasculogenesis and angiogenesis $(5,42-44)$, epithelial to mesenchymal transition $(44,45)$ and implantation (2). In the adult, ets-1 is expressed in the granulation tissue during wound healing, but also in endothelial cells of solid tumours $(7,46)$ and in the tissue stroma in reaction to tumours $(6,47)$. Ets- 1 is also expressed in hematopoietic cells (45) during the lymphoid differentiation (48) and seems to play an important role in T-cell survival (49) and the establishment of NK cells (50). In all these reports, the full-length Ets-1 was commonly considered to be the active form and the role of the Ets-1 $\Delta$ VII splice variant has not been addressed in detail. Therefore we examined here the role of Ets-1 $\Delta$ VII splice variant in comparison to the full-length Ets-1 in mouse fibroblasts in regard to known Ets-1 target genes. Our results demonstrate that $\mathrm{p} 42$ Ets-1 has quite different functions and target genes compared to p51 Ets-1 (e.g. TIMP-4, MMP-3, MMP-9, MMP-13). In some case (e.g. in cytokine expression) p42 Ets-1 is a functional transcription factor which acts in the same manner as a transdominant negative approach. Therefore we postulate that $\mathrm{p} 42$ Ets- 1 binds to the same core DNA recognition sites as p51 Ets- 1 and thereby the Ets- $1 \Delta$ VII splice variant prevents the binding of full length Ets-1. Previously it has been demonstrated by Lionneton et al that the mouse Ets-1 $\Delta$ VII splice variant beside the ETS binding site also recognized a site similar to the Spi-1/PU.1 DNA recognition site (30). It is well known that the effects of transcription factors onto their target genes, activation as well as repression, is mediated by co-factors and intermediates. In the case of Ets-1 the splice variant $\mathrm{p} 42$ could have a different set of co-factors compared to the full-length protein or the co-factors are unable to bind to the $\Delta$ VII splice variant.

Previously it has been demonstrated that Ets-1 $\Delta$ VII splice variant escapes calcium-dependent inactivation and shows much higher DNA-binding activity than full-length Ets-1 $(28,29)$. It has been suggested that Ets-1 $\Delta$ VII splice variant compete with or compensate the function of the full-length transcript even when expression levels are lower than that of p51.

Recently we studied the effects of Ets-1 in mouse embryonal fibroblasts by comparing wild-type fibroblasts with fibroblasts derived from ets- 1 knock-out mouse (51). The Ets- $1 \Delta$ VII splice variant was not detected in the wild-type or in the Ets-1 ${ }^{-1}$ fibroblasts (51). We found that basal full-length Ets-1 levels are necessary for a fast induction of MMP-2, -3, -9 and -13 by bFGF (51). In contrast to the results obtained with mouse embryonal fibroblasts we found MMP-3 and MMP-13 expression only in NIH3T3 cells expressing the Ets-1 $\Delta$ VII splice variant. This discrepancy could be most probably explained by the differences between primary cells and an established cell line. Furthermore it is possible that during embryogenesis and bFGF stimulation another set of co-factors is expressed resulting in different MMP expression pattern compared to the MMP expression in an immortalised cell line. In mouse embryonal fibroblasts the basal full-length Ets-1 levels are also found to be necessary for a maintenance of bFGF-induced expression of tissue inhibitors of metalloproteinases 1,2 and 3 known to not only inhibit but also to participate in activation of certain pro-MMPs (51). Of special interest we found no TIMP-4 expression in these embryonal fibroblasts (51). So it seems that TIMP-4 expression is directly linked to the Ets-1 $\Delta$ VII splice variant. Furthermore, we observed in a reporter gene assay the strongest transcriptional activity of the TIMP-4 promoter in 3T3-Ets-1 $\Delta$ VII cells.

In regard to the fact that overexpression of TIMP-4 has been shown to inhibit growth and invasion of tumour cells (52-54) the Ets-1 $\Delta$ VII splice variant could exert at least to a certain degree the observed increase in cell attachment, the decreased capacity for anchorage-independent growth and the reduced invasive behaviour through the activation of TIMP-4 expression.

The cytokine IL-1 $\beta$ is known to induce the expression of adhesions molecules on various cell types (55). Therefore the increased expression of IL-1 $\beta$ detected in 3T3-Ets- $1 \Delta \mathrm{VII}$ and 3T3-Ets-1-DB cells could also result in the observed increase in cell attachment. In agreement with the increased cell attachment is also the high expression level of integrin $\beta 2$ in 3T3-Ets-1 $\Delta$ VII cells, but in 3T3-Ets-1-DB cells the integrin $\beta 2$ expression was very low. This finding suggests that other adhesion molecules must have a higher impact on the cell attachment behaviour. Moreover, it is well established that integrin $\beta 2$ besides mediating interactions between adhesions molecules is involved in triggering intracellular signalling (56). Therefore the expression level of integrin $\beta 2$ is not necessarily correlated with the extent of adhesion. 
In conclusion, our results suggest that the Ets-1 $\Delta$ VII splice variant has different functions in comparison to the full-length Ets-1 in mouse fibroblasts. The highest differences between the full-length Ets-1 and the Ets-1 $\Delta$ VII splice variant are found in the cytokine expression profile as well as in MMP and TIMP expression patterns.

\section{Acknowledgements}

This work was supported by German Research Association (DFG grant no. WE 1104/11-1) and German Cancer Aid (Deutsche Krebshilfe grant no. 107827).

\section{References}

1. Adam M, Schmidt D, Wardelmann E, Wernert $\mathrm{N}$ and Albers $\mathrm{P}$. Angiogenetic protooncogene ets-1 induced neovascularization is involved in the metastatic process of testicular germ cell tumors. Eur Urol 44: 329-336, 2003.

2. Grevin D, Chen JH, Raes MB, Stehelin D, Vandenbunder B and Desbiens X: Involvement of the proto-oncogene c-ets 1 and the urokinase plasminogen activator during mouse implantation and placentation. Int J Dev Biol 37: 519-529, 1993.

3. Khatun S, Fujimoto J, Toyoki H and Tamaya T: Clinical implications of expression of ETS-1 in relation to angiogenesis in ovarian cancers. Cancer Sci 94: 769-773, 2003.

4. Pourtier-Manzanedo A, Vercamer C, Van Belle E, Mattot V, Mouquet $\mathrm{F}$ and Vandenbunder B: Expression of an Ets-1 dominant-negative mutant perturbs normal and tumor angiogenesis in a mouse ear model. Oncogene 22: 1795-1806, 2003.

5. Vandenbunder B, Pardanaud L, Jaffredo T, Mirabel MA and Stehelin D: Complementary patterns of expression of c-ets 1 , $\mathrm{c}$-myb and c-myc in the blood-forming system of the chick embryo. Development 107: 265-274, 1989.

6. Wernert N, Gilles F, Fafeur V, Bouali F, Raes MB, Pyke C, Dupressoir T, Seitz G, Vandenbunder B and Stehelin D: Stromal expression of c-Ets1 transcription factor correlates with tumor invasion. Cancer Res 54: 5683-5688, 1994.

7. Wernert N, Raes MB, Lassalle P, Dehouck MP, Gosselin B, Vandenbunder B and Stehelin D: c-ets1 proto-oncogene is a transcription factor expressed in endothelial cells during tumor vascularization and other forms of angiogenesis in humans. Am J Pathol 140: 119-127, 1992.

8. Behrens P, Mathiak M, Mangold E, Kirdorf S, Wellmann A, Fogt F, Rothe M, Florin A and Wernert N: Stromal expression of invasion-promoting, matrix-degrading proteases MMP-1 and -9 and the Ets 1 transcription factor in HNPCC carcinomas and sporadic colorectal cancers. Int J Cancer 107: 183-188, 2003.

9. Behrens P, Rothe M, Florin A, Wellmann A and Wernert N: Invasive properties of serous human epithelial ovarian tumors are related to Ets-1, MMP-1 and MMP-9 expression. Int J Mol Med 8: 149-154, 2001.

10. Behrens P, Rothe M, Wellmann A, Krischler J and Wernert N: The Ets-1 transcription factor is up-regulated together with MMP 1 and MMP 9 in the stroma of pre-invasive breast cancer. J Pathol 194: 43-50, 2001.

11. Wernert N: The multiple roles of tumour stroma. Virchows Arch 430: 433-443, 1997

12. Westermarck $\mathbf{J}$ and Kahari VM: Regulation of matrix metalloproteinase expression in tumor invasion. FASEB J 13: 781-792, 1999.

13. Hahne JC, Okuducu AF, Kaminski A, Florin A, Soncin F and Wernert N: Ets-1 expression promotes epithelial cell transformation by inducing migration, invasion and anchorage-independent growth. Oncogene 24: 5384-5388, 2005.

14. Wasylyk B, Hahn SL and Giovane A: The Ets family of transcription factors. Eur J Biochem 211: 7-18, 1993

15. Baker KM, Wei G, Schaffner AE and Ostrowski MC: Ets-2 and components of mammalian SWI/SNF form a repressor complex that negatively regulates the BRCA1 promoter. J Biol Chem 278 : 17876-17884, 2003.

16. Maurer P, T'Sas F, Coutte L, Callens N, Brenner C, Van Lint C, de Launoit $Y$ and Baert JL: FEV acts as a transcriptional repressor through its DNA-binding ETS domain and alanine-rich domain. Oncogene 22: 3319-3329, 2003.
17. Meraro D, Gleit-Kielmanowicz M, Hauser H and Levi BZ: IFN-stimulated gene 15 is synergistically activated through interactions between the myelocyte/lymphocyte-specific transcription factors, PU.1, IFN regulatory factor-8/IFN consensus sequence binding protein, and IFN regulatory factor-4: characterization of a new subtype of IFN-stimulated response element. J Immunol 168: 6224-6231, 2002.

18. Sgouras DN, Athanasiou MA, Beal GJ, Fisher RJ, Blair DG and Mavrothalassitis GJ: ERF: an ETS domain protein with strong transcriptional repressor activity, can suppress ets-associated tumorigenesis and is regulated by phosphorylation during cell cycle and mitogenic stimulation. EMBO J 14: 4781-4793, 1995.

19. Soudant N, Albagli O, Dhordain P, Flourens A, Stehelin D and Leprince D: A residue of the ETS domain mutated in the v-ets oncogene is essential for the DNA-binding and transactivating properties of the ETS-1 and ETS-2 proteins. Nucleic Acids Res 22: $3871-3879,1994$

20. Starck J, Cohet N, Gonnet C, Sarrazin S, Doubeikovskaia Z, Doubeikovski A, Verger A, Duterque-Coquillaud M and Morle F: Functional cross-antagonism between transcription factors FLI-1 and EKLF. Mol Cell Biol 23: 1390-1402, 2003.

21. Waga K, Nakamura Y, Maki K, Arai H, Yamagata T, Sasaki K, Kurokawa M, Hirai H and Mitani K: Leukemia-related transcription factor TEL accelerates differentiation of Friend erythro leukemia cells. Oncogene 22: 59-68, 2003.

22. Yang J, Shultz RW, Mars WM, Wegner RE, Li Y, Dai C, Nejak K and Liu Y: Disruption of tissue-type plasminogen activator gene in mice reduces renal interstitial fibrosis in obstructive nephropathy. J Clin Invest 110: 1525-1538, 2002.

23. Hollenhorst PC, Jones DA and Graves BJ: Expression profiles frame the promoter specificity dilemma of the ETS family of transcription factors. Nucleic Acids Res 32: 5693-5702, 2004

24. Mattot V, Vercamer C, Soncin F, Calmels T, Huguet C, Fafeur V and Vandenbunder B: Constitutive expression of the DNA-binding domain of Ets1 increases endothelial cell adhesion and stimulates their organization into capillary-like structures. Oncogene 19: 762-772, 2000

25. Petersen JM, Skalicky JJ, Donaldson LW, McIntosh LP, Alber T and Graves BJ: Modulation of transcription factor Ets-1 DNA binding: DNA-induced unfolding of an alpha helix. Science 269: 1866-1869, 1995.

26. Jonsen MD, Petersen JM, Xu QP and Graves BJ: Characterization of the cooperative function of inhibitory sequences in Ets-1. Mol Cell Biol 16: 2065-2073, 1996.

27. Garvie CW, Pufall MA, Graves BJ and Wolberger C: Structural analysis of the autoinhibition of Ets-1 and its role in protein partnerships. J Biol Chem 277: 45529-45536, 2002.

28. Rabault B and Ghysdael J: Calcium-induced phosphorylation of ETS1 inhibits its specific DNA binding activity. J Biol Chem 269: 28143-28151, 1994

29. Cowley DO and Graves BJ: Phosphorylation represses Ets-1 DNA binding by reinforcing autoinhibition. Genes Dev 14: 366-376, 2000.

30. Lionneton F, Lelievre E, Baillat D, Stehelin D and Soncin F: Characterization and functional analysis of the p42Ets-1 variant of the mouse Ets-1 transcription factor. Oncogene 22: 9156-9164, 2003.

31. Jorcyk CL, Watson DK, Mavrothalassitis GJ and Papas TS: The human ETS1 gene: genomic structure, promoter characterization and alternative splicing. Oncogene 6: 523-532, 1991.

32. Bellacosa A, Datta K, Bear SE, Patriotis C, Lazo PA, Copeland NG, Jenkins NA and Tsichlis PN: Effects of provirus integration in the Tpl-1/Ets-1 locus in Moloney murine leukemia virus-induced rat T-cell lymphomas: levels of expression, polyadenylation, transcriptional initiation, and differential splicing of the Ets-1 mRNA. J Virol 68: 2320-2330, 1994.

33. Koizumi S, Fisher RJ, Fujiwara S, Jorcyk C, Bhat NK, Seth A and Papas TS: Isoforms of the human ets-1 protein: generation by alternative splicing and differential phosphorylation. Oncogene 5: 675-681, 1990.

34. Fisher RJ, Fivash M, Casas-Finet J, Erickson JW, Kondoh A, Bladen SV, Fisher C, Watson DK and Papas T: Real-time DNA binding measurements of the ETS1 recombinant oncoproteins reveal significant kinetic differences between the p42 and p51 isoforms. Protein Sci 3: 257-266, 1994.

35. Huang CC, Papas TS and Bhat NK: A variant form of ETS1 induces apoptosis in human colon cancer cells. Oncogene 15: 851-856, 1997. 
36. Li R, Pei H and Papas T: The p42 variant of ETS1 protein rescues defective Fas-induced apoptosis in colon carcinoma cells. Proc Natl Acad Sci USA 30: 3876-3881, 1999.

37. Graham FL and van der Eb AJ: Transformation of rat cells by DNA of human adenovirus 5. Virology 54: 536-539, 1973

38. Loyter A, Scangos GA and Ruddle FH: Mechanisms of DNA uptake by mammalian cells: fate of exogenously added DNA monitored by the use of fluorescent dyes. Proc Natl Acad Sci USA 79: 422-426, 1982.

39. Wadman IA, Osada H, Grutz GG, Agulnick AD, Westphal H, Forster A and Rabbitts TH: The LIM-only protein Lmo2 is a bridging molecule assembling an erythroid, DNA-binding complex which includes the TAL1, E47, GATA-1 and Ldb1/NLI proteins. EMBO J 16: 3145-3157, 1997.

40. Jesnowski R, Backhaus C, Ringel J and Lohr M: Ribosomal highly basic $23-\mathrm{kDa}$ protein as a reliable standard for gene expression analysis. Pancreatology 2: 421-424, 2002.

41. Hynes RO, Lively JC, McCarty JH, Taverna D, Francis SE, Hodivala-Dilke K and Xiao Q: The diverse roles of integrins and their ligands in angiogenesis. Cold Spring Harb Symp Quant Biol 67: 143-153, 2002.

42. Maroulakou IG, Papas TS and Green JE: Differential expression of ets-1 and ets-2 proto-oncogenes during murine embryogenesis. Oncogene 9: 1551-1565, 1994

43. Pardanaud L and Dieterlen-Lievre F: Expression of C-ETS1 in early chick embryo mesoderm: relationship to the hemangioblastic lineage. Cell Adhes Commun 1: 151-160, 1993.

44. Queva C, Leprince D, Stehelin D and Vandenbunder B: p54cets-1 and p68c-ets-1, the two transcription factors encoded by the c-ets-1 locus, are differentially expressed during the development of the chick embryo. Oncogene 8: 2511-2520, 1993.

45. Kola I, Brookes S, Green AR, Garber R, Tymms M, Papas TS and Seth A: The Ets1 transcription factor is widely expressed during murine embryo development and is associated with mesodermal cells involved in morphogenetic processes such as organ formation. Proc Natl Acad Sci USA 90: 7588-7592, 1993.

46. Vandenbunder B, Queva C, Desbiens X, Wernert N and Stehelin D: Expression of the transcription factor c-Ets1 correlates with the occurrence of invasive processes during normal and pathological development. Invasion Metastasis 14: 198-209, 1994.
47. Calmels TP, Mattot V, Wernert N, Vandenbunder B and Stehelin D: Invasive tumors induce c-ets1 transcription factor expression in adjacent stroma. Biol Cell 84: 53-61, 1995.

48. Anderson MK, Hernandez-Hoyos G, Diamond RA and Rothenberg EV: Precise developmental regulation of Ets family transcription factors during specification and commitment to the T cell lineage. Development 126: 3131-3148, 1999.

49. Bories JC, Willerford DM, Grevin D, Davidson L, Camus A, Martin P, Stehelin D and Alt FW: Increased T-cell apoptosis and terminal B-cell differentiation induced by inactivation of the Ets-1 proto-oncogene. Nature 377: 635-638, 1995.

50. Barton K, Muthusamy N, Fischer C, Ting CN, Walunas TL, Lanier LL and Leiden JM: The Ets-1 transcription factor is required for the development of natural killer cells in mice. Immunity 9: 555-563, 1998.

51. Hahne JC, Fuchs T, El Mustapha H, Okuducu AF, Bories JC and Wernert N: Expression pattern of matrix metalloproteinase and TIMP genes in fibroblasts derived from Ets-1 knock-out mice compared to wild-type mouse fibroblasts. Int J Mol Med 18: 153-159, 2006.

52. Wang M, Liu YE, Greene J, Sheng S, Fuchs A, Rosen EM and Shi YE: Inhibition of tumor growth and metastasis of human breast cancer cells transfected with tissue inhibitor of metalloproteinase 4. Oncogene 14: 2767-2774, 1997.

53. Hilska M, Roberts PJ, Collan YU, Laine VJ, Kossi J, Hirsimaki P, Rahkonen $\mathrm{O}$ and Laato $\mathrm{M}$ : Prognostic significance of matrix metalloproteinases- $1,-2,-7$ and -13 and tissue inhibitors of metalloproteinases- $1,-2,-3$ and -4 in colorectal cancer. Int J Cancer 121: 714-723, 2007.

54. Guo YH, Gao W, Li Q, Li PF, Yao PY and Chen K: Tissue inhibitor of metalloproteinases-4 suppresses vascular smooth muscle cell migration and induces cell apoptosis. Life Sci 75: 2483-2493, 2004.

55. Yang CM, Luo SF, Hsieh HL, Chi PL, Lin CC, Wu CC and Hsiao LD: Interleukin-1beta induces ICAM-1 expression enhancing leukocyte adhesion in human rheumatoid arthritis synovial fibroblasts: involvement of ERK, JNK, AP-1, and NF-kappaB. J Cell Physiol 224: 516-526, 2010.

56. Jakus Z, Fodor S, Abram CL, Lowell CA and Mócasai A: Immunoreceptor-like signaling by beta 2 and beta 3 integrins. Trends Cell Biol 17: 493-501, 2007. 